\title{
$\begin{array}{ll}\text { Research Square } & \text { Preprints are preliminary reports that have not undergone peer review. } \\ \text { They should not be considered conclusive, used to inform clinical practice, }\end{array}$
}

\section{Road safety situation of courier and take-out food delivery electric bike riders: a cross-sectional study in one municipality in China}

\section{Zhuo Wang ( $\nabla$ wangzhuo521@126.com )}

Tianjin Centers for Disease Control and Prevention https://orcid.org/0000-0001-9727-3352

\section{Guohong Jiang}

Tianjin Center for Disease Control and Prevention

\section{Richard L. Neitzel}

University of Michigan

\section{Wenlong Zheng}

Tianjin Centers for Disease Control and Prevention

\section{Dezheng Wang}

Tianjin Centers for Disease Control and Prevention

Xiaodan Xue

Tianjin Centers for Disease Control and Prevention

\section{Research article}

Keywords: Injury, Electric-bike, Traffic violation behaviors, Courier, Take-out food deliveryman

Posted Date: June 9th, 2020

DOI: https://doi.org/10.21203/rs.3.rs-31421/v1

License: (c) (i) This work is licensed under a Creative Commons Attribution 4.0 International License. Read Full License 


\section{Abstract}

Background To observe road traffic violation behaviors among courier and take-out food delivery electric bike rider and to characterize road traffic injuries occurred in this occupational population.

Methods A cross-sectional field study including roadside observational data collection and face-to-face interviews was conducted by retrospective response through street intercept.

Results 600 target populations were observed, and 480 were interviewed. The rate of over speed was $91.3 \%$, and windshield use during winter was $91.2 \%$. Traffic rule violations included riding in the motor vehicle lane (32.8\%), not waiting behind the white line at a red light (23.3\%), and using a cell phone when riding (21.2\%). Helmet use was significantly more common in daytime than night $(\mathrm{P}=0.028)$. About $46 \%$ rode e-bike more than 8 hours per day. $76 \%$ of interviewees had suffered a traffic crash. About $14 \%$ crashes happened in motor-vehicle lanes and $8 \%$ in sidewalks. A logistic regression analysis indicated that compared with uninjured riders, injured riders showed significantly greater odds ratios of unsafe behaviors for running red lights $(\mathrm{OR}=1.75)$, and a protective effect for wearing a helmet $(\mathrm{OR}=0.56)$.

Discussion Road safety issues need to be addressed through establishment or improvement of e-bike legislation in this vulnerable occupational group.

\section{Background}

In recent years, with the increasing popularity and use of smart phones, electronic commerce has boomed and matured in China. As a result, the online shopping and take-out food delivery service industry in China has developed at an amazing speed ${ }^{[1]}$.According to the "China Internet network development state statistic report" issued by the China Internet network information center (CNNIC) in Beijing, as of June 2017, the total number of online shoppers in China reached 514 million, an increase of $10.2 \%$ compared to the end of 2016. The number of shoppers using mobile phones has reached 480 million, and the number is still increasing. In China, except for some state-owned express delivery enterprises (EMS) and foreign

investment express enterprises (UPS, FedEx) who drive motor vehicles as the main transport method ${ }^{[1]}$, most private courier and delivery enterprises use electric bikes (e-bikes) as the main mode of transportation within urban areas.

E-bikes have become the most popular transportation mode among the Chinese population in recent years. The production of e-bikes increased nearly exponentially, from 58000 in 1998, to 21 million in $2008^{\text {[2] }}$ to 120 million in 2011 in China [3] Meanwhile, the number of crashes and deaths related to e-bikes increases each year. The rate of nonfatal injuries related to e-bikes increased almost four-fold, and the mortality rate increased six-fold, from 2004 to 2010 [2]. The Ministry of Public Security recently announced that, during the five years from 2013 to 2017, a total of 56 thousand people were killed or injured in crashes involving e-bikes in China, resulting in 8431 deaths, 63 thousand injuries, and 11.1 million direct property losses. China is clearly facing new public health challenges arising from e-bike-use.

Non-motor vehicle riders are vulnerable road users, and courier and take-out food delivery e-bike riders may be among the most vulnerable people in this group. Express and take-out food delivery is a recent development in China. In China, workers in this industry don't need a lot of education and receive lower income, as well as weaker road safety awareness. Due to fierce competition, express delivery services require their employees to serve their customers in a very short specified time. As a result, these delivery workers are in much more of a hurry than the typical E-bike riders, and may have a higher incidence of crashes as a result. Traffic violations are particularly common among e-bike riders in this industry.

Despite the apparent risks to this vulnerable group, our understanding of unsafe behaviors and injury experience among these workers in this emerging industry is very inadequate. Using a combination of observations and interviews, this study conducted a field investigation to better understand the behaviors and direct and indirect burden of road traffic injuries among delivery workers who ride e-bikes. 


\section{Method}

\section{Study Setting}

As one of the four municipalities of China, Tianjin is in the northeast of China with a resident population of approximately 15.6 million and population density of 1300 per square kilometer in $2016^{[4]}$. Tianjin has become the largest e-bike production and sales base in China.

Because of their convenience, speed, ease of use, and relatively low price, e-bikes have become popular and are now extensively used. E-bikes are treated as the primary mode of transportation by both ordinary residents and courier and takeout food delivery workers in Tianjin and other large and medium-sized cities all over China. However, e-bike traffic violation behaviors in courier and take-out food delivery workers appear to be quite common. These behaviors are likely taken in order to save time and deliver more orders, but may lead to serious road traffic injury. Given that little is known about the road traffic injury situation of this occupational population, we conducted a program, supported by the Global Road Safety Program, which aimed to evaluate and reduce e-bike injuries and promote social concerns about e-bike. As part of this program, we conducted a cross-sectional study in Tianjin.

\section{Measurements}

Our study was divided into 2 components. The first was a roadside observation of e-bike rider behaviors, and the second was a field survey using rider interviews. All of six urban districts of Tianjin were included. The participants were informed about the purpose of the study before they answered the questionnaire. Both observation record and investigation were anonymous.

\section{Observations}

One arterial road and one sub-arterial road were selected for observations in each district. Investigators were trained by designer in order to ensure standards of observation uniform. One hundred courier and food delivery worker e-bike riders were observed by trained investigators standing on the roadside in each district. Observers identified courier and food delivery e-bike riders by their work clothes with different food delivery company logos. The observers did not intervene or disturb the e-bike riders in any way. The speed of the observed e-bike riders was assessed visually by experienced observers; the designed speed limit of e-bikes in China is $20 \mathrm{~km} / \mathrm{h}$. Observed rider behaviors were recorded using a checklist. These included five traffic violation behaviors (riding in the incorrect direction for the lane, running a red light, not waiting behind the white line at a red light, and using a cell phone when riding), and three protective behaviors (using a windshield during winter, wearing a helmet, having reflectors on the e-bike, and using a light on the e-bike). Both daytime (11:00-14:00) and night (18:00-20:00) were included. Observations took place on two workdays and two weekends. The average temperature all day was $3^{\circ} \mathrm{C}$ to $13^{\circ} \mathrm{C}$ during the observation period.

\section{Survey}

Eighty courier and take-out food delivery e-bike riders were intercepted in each district and offered the opportunity to be interviewed. The respondents provided basic information and specific crash information (Table 1). The survey was anonymous. The severity of traffic crash injuries was divided into 4 categories: uninjured, light, medium and serious. "Light" refers to superficial and slight injury, "medium" refers to fracture or suture injury, "severe" refers to emergency or immediate surgery. Finally, the participants' attitude towards special e-bike management regulations were also enquired .

\section{Statistical Analysis}

All analysis was performed with the SPSS statistical package, version 24.0. Pearson Chi-square tests were used to analyze frequency data, and independent sample t-tests were used to assess quantitative data. Odds ratios for risk of being injured 
were estimated for specific traffic violation and protective behaviors using logistic regression. A $P$ value less than 0.05 was regarded as statistically significant.

\section{Results}

Six hundred courier and take-out food delivery worker e-bike riders were observed, and 480 were interviewed as part of our study.

\section{Observations}

The rates of observed road traffic violation behaviors were very high (Table 2). More than $90 \%$ of observations documented speeds more than $20 \mathrm{~km} / \mathrm{h}$ ). Windshield usage (quilt) was approximately $91 \%$. Nearly $33 \%$ of observations documented riders riding in the motor vehicle lane while e-bike riders did not wait behind the white line at red lights and used cell phones when riding in more than $20 \%$ of observations. Helmet use was not optimal; in the daytime, $73 \%$ of riders were wearing helmets, while only about $65 \%$ were at night. This difference between daytime and nighttime helmet usage was statistically significant $(P=0.028)$.

\section{Surveys}

Among 480 survey respondents, 432 were male (90.0\%) and 48 were female (10.0\%). Two hundred seventy participants were take-out food delivery workers (56.3\%), and 210 were couriers (43.8\%). Among the interviewees, $103(21.5 \%)$ were Tianjin urban household registration, 91 (19.0\%) were Tianjin rural household registration, and $286(59.6 \%)$ were other provincial household registration (i.e., floating population). The average employment time was $17.9 \pm 15.0$ months ( range 1 to 84 months) and the average number of working days per week was $6.3 \pm 0.8$ day. Of the 480 interviewees, 411 (85.6\%) worked more than 6 day every week, and 233 (46.5\%) rode more than $8 \mathrm{~h}$ per day; the average riding duration per day was $7.2 \pm 2.2 \mathrm{~h}$ (range $2 \mathrm{~h}$ to $13 \mathrm{~h}$ ).

Among the 480 interviewees, $367(76.46 \%)$ had suffered a traffic crash. The number of crashes they suffered ranges from 1 to 9 , and the average number was $1.9 \pm 1.2$ times. Courier delivery workers had fewer crashes than take-away delivery workers ( $1.7 \pm 1.1$ vs. $2.1 \pm 1.3$, respectively); this difference was statistically significant $(P=0.001)$. Among the $367(76.5 \%)$ participants who suffered crashes, 129 (35.1\%) were riding in the wrong direction when the crash happened.

Table 3 shows information about injured riders' behaviors related to the worst traffic crash during their career. Courier and take-out food delivery worker e-bike riders most often crashed into other e-bikes ( $25.6 \%$ of crashes), followed by pedestrians (24.5\%), bicycles (24.0\%), and motor vehicles (16.6\%). In terms of crash location, the majority of crashes occurred at an intersection (44.7\%) or a non-motor vehicle lane (33.2\%). A total of $22.1 \%$ of crashes occurred at locations where e-bike riding is prohibited.

Table 3 shows the severity of the reported injuries from the worst traffic crashes. Riders in 193 of the 367 crashes (52.6\%) crashes were "uninjured", 148 (40.3\%) were "light" injuries, 24 (6.5\%) were "medium," and 2 (0.5\%) were "serious." Fig 1 shows that lower limbs (17.2\%) and upper limbs (16.9\%) are the most common injury parts in all $(n=367)$.

Table 4 shows the incidence rate of riding behaviors and OR (and 95\% $\mathrm{Cl}$ ) between injured and uninjured courier and takeout food delivery worker e-bike riders who had crashes $(n=367)$. Compared with uninjured e-bike riders, injured riders showed greater ORs for violation behaviors, such as riding in the incorrect lane direction $(\mathrm{OR}=1.26,95 \% \mathrm{Cl} 0.82$ to 1.94$)$, running a red light $(\mathrm{OR}=1.75,95 \% \mathrm{Cl} 1.01$ to 3.06$)$, and riding in a motor vehicle lane $(\mathrm{OR}=1.73,95 \% \mathrm{Cl} 0.75$ to 3.96$)$. Odds ratios of injury increased with increasing speed, though the ORs were not statistically significant in all speed categories. Speeds less than $15 \mathrm{~km} /$ hour and wearing a helmet were associated with reduced ORs for injury, though only the OR for wearing a helmet was statistically protective, significantly. 
In terms of the burden among injured E-bike riders $(n=174), 28.7 \%(n=50)$ missed work because of the injury. The average number of days off for the 50 workers who missed work was $7.1 \pm 7.1$ days.

Finally, when riders were asked about their attitudes toward e-bike special management regulations, $50.8 \%$ of the 480 surveyed riders $(n=244)$ were very supportive, $32.1 \%(n=154)$ were supportive, $16.3 \%(n=78)$ did not care, $0.8 \%(n=4)$ were opposed.

\section{Discussion}

According to the World Health Organization, road traffic injury were responsible for approximately $12 \%$ of deaths worldwide in 2012 ${ }^{\mathrm{Q9} \mathrm{Q}}$. Road traffic injuries (RTIs) have also become the leading cause of injury-related death, and a primary cause of

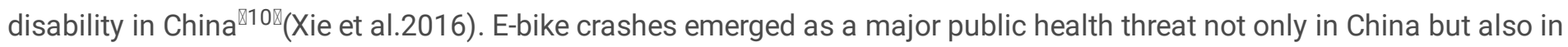

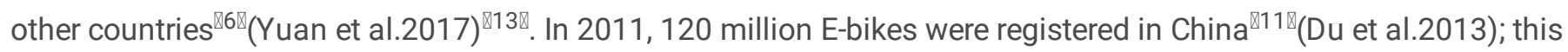
accounts for up to $90 \%$ of the global market ${ }^{\bigotimes 11}$ (Du et al.2013), and the number of registered bikes in China and elsewhere continues to increase. Consequently, e-bike-related deaths increased almost seven times between 2004 (589 deaths) and 2010 (4029 deaths), while bicycle-related deaths decreased by a factor of three during the same period ${ }^{\llbracket 12 \rrbracket}$ (Jie Yang). The number of road traffic injury involving casualties caused by e-bikes is increasing $8.6 \%$ annually, and the number of e-bike deaths has been increasing 13.5\% annually. In China, bicycle use is changing into e-bike use. In the cities of China, most of the courier and take-out food delivery workers e-bike riders are migrants. The industry also has a high turnover of workers.

Our survey results indicated that the average employment time of the interviewees was 17.9 months. However, $76.5 \%$ of them had suffered traffic crashes during this short employment time. More than $85 \%$ of e-bike rider worked more than 6 days per week, with an average riding time of 7 hours per day, and a maximum time of 13 hours. Due to the long riding time and exposure on the road, these occupational populations have a very high risk of road traffic injury. Their work is highintensity, mobile, and has a low educational need and low income. Therefore, these workers may be considered exceptionally vulnerable road users.

\section{Observations}

A few other studies have assessed riding behaviors and attitudes among e-bike riders. In Denmark, riding style and e-bike

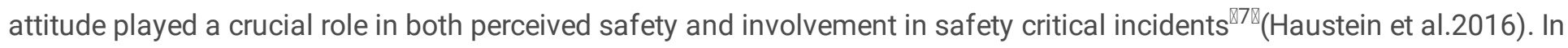
the Netherlands, e-bike users were also more likely to be involved in a crash ${ }^{\llbracket 8 \otimes}$ (Schepers et al.2014). This phenomenon is even more prominent in China. Unsafe riding practices such as speeding, road rule violations and lack of helmet use have previously been shown to be commonplace among e-bikers in China ${ }^{\text {12】 }}$.

In this study, we found that traffic violation behaviors in courier and take-out food delivery worker e- bike riders are much more pronounced than in the general public. The occurrence rate of over speed was $91.3 \%$, followed by riding in motor vehicle lanes and not waiting behind the white line at a red light. Driving in the incorrect lane direction, running a red light, and using a cell phone were less common, but still occurred in roughly $20 \%$ of observations. The traffic violation behaviors of this occupational population are much more serious than an observational study in Suzhou, China, which showed $70.9 \%$ exceeded the designed speed limit of $20 \mathrm{~km} / \mathrm{h}$, and that $38.3 \%$ did not comply with the road rules when entering intersections ${ }^{\bigotimes 12 \rrbracket}$.

With regard to helmet use, the overall rate of helmet use was $68.83 \%$ in courier and take-out food delivery workers. The rate of helmet use at night (64.5\%) was lower than daytime (73.0\%), and this difference was statistically significant. Helmet use is even worse among non-commercial e-bike riders. Jie Yang reported only $2.2 \%$ of riders wore helmets among resident ebike riders in Suzhou ${ }^{\bigotimes 12 \rrbracket}$. The relatively higher helmet use among riders observed in this study maybe be due to employer regulations on wearing helmets. If true, this would suggest that industry or company regulations may be effective at 
regulating the behavior of courier and take-out food delivery riders. Therefore, in the absence of a national or local law concerning e-bikes, industry regulations need to be established and strengthened.

This study was conducted in the late autumn and early winter, during which time the average temperature was $3^{\circ} \mathrm{C}$ to 13 ${ }^{\circ} \mathrm{C}$. This allowed for assessment of windshield use, which was seen in $91.2 \%$ of observations. Wind shields are often installed to reduce exposure to wind and associated wind chill in the cold northern area of China, such as in Tianjin city. However, this is an unsafe practice when operating an e-bike, because of some of the wind shields have integrated gloves and kneepads, and some windshields also cover riders' upper bodies. Wind shield use is dangerous to e-bike riders, as the shield will interfere with the handlebars during sharp turns, and may become loose and require reattachment while riding. The windshield can also interfere with the rider's ability to support the bike with two feet on the ground. Therefore, we suggest that installing wind shields on e-bikes should be prohibited by local or national regulations.

Surveys

Road safety consciousness and self-protection awareness appeared to be weak among courier and take-out food delivery workers riding e-bikes, and crashes and injuries were common. We found that courier and take-away delivery workers riding e-bikes most commonly crashed into other e-bikes, pedestrians, and bicycle riders. More than three-quarters of crashes occurred in intersections or in non-motor vehicle lanes. Traffic violation behaviors of e-bike riders were commonplace, and these violations appear to be more common than those among non-commercial e-bike riders. Although riding in motor vehicle lanes and on sidewalks are traffic violation behaviors ${ }^{[13]}$, almost $14 \%$ of crashes happened in motor vehicle lanes, and $8 \%$ on sidewalks, in our study.

Pedestrians, cyclists, and e-bike riders are the most disadvantaged road users ${ }^{\bigotimes 16 囚(N a n t u l y a ~ 2003) . ~ I n ~ l o w-~ a n d ~ m i d d l e-~}$ income countries, they are the main road users and the main injury group in traffic crash ${ }^{\bigotimes 17 \rrbracket}$ (Duan et al. 2010), ${ }^{\text {18区 }}$ (Nantulya and Reich 2002). However, our investigation indicated that e-bike riders frequently do not comply with traffic rules. If ebikers ride in their own non- motor vehicle lane, e-bike crashes happen on sidewalks and in motor vehicle lanes would be reduced. Similarly, e-bike crashes in intersections should be reduced by e-bike riders choosing to obey traffic lights, and collisions in non-motor vehicle lanes can be reduced by avoiding speeding.

More than one third (35.2\%) of accidental crash happened when e-bike riders were riding in the incorrect direction of a traffic lane in our study. Rider behavior also plays an important role in injury severity. We observed rider running red lights in nearly $17 \%$ of our observations, and this behavior was significantly associated with injury risk when we compared injured (20.7\%)

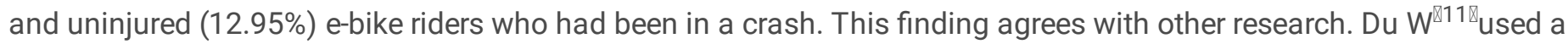
cross-sectional observational study to describe different on-road riding behaviors among E-bikers and reported that $26.6 \%$ did not comply with the road rules. The overall prevalence of carrying passengers, riding in a motor vehicle lane, running red lights, riding in opposite directions, mobile phone use, and helmet use were $12.4 \%, 1.9 \%, 4.8 \%, 3.4 \%, 0.4 \%$, and $9.0 \%$, respectively in his study ${ }^{\nabla 11}$. Analysis has revealed that, in China, over 60 percent of fatal crashes involving 2-wheelers result from traffic rule violations (China Road Traffic Accidents Statistics Report 2004). In our previous study, 132 patients, nearly two thirds of the total, violated traffic rules. E-bikers hospitalized for injuries accounted for $57 \%$ of serious non-fatal road traffic injuries and $50 \%$ of the direct hospitalization cost for all road crash casualties in a rural hospital in Suzhou ${ }^{\otimes 12 \rrbracket}\left(\mathrm{Jie}^{\mathrm{B}}\right.$ Yang).

Wearing a helmet is an effective protective behavior, and the use of a helmet was significantly different between injured (51.7\%) and uninjured (65.8\%) e-bike riders in our study. Approximately one-third (32.7\%) of traffic injuries were e-bikerelated in Zhejiang Provincial People's Hospital in China from 2008 to 2011, and the head was the most commonly injured body region $(31.1 \%)^{\otimes 19}$. Feng Hu reported that injury severity is commonly sustained within crash mode $(\mathrm{OR}=11.56)$ and traffic rule violations $(\mathrm{OR}=4.74)^{\bigotimes 15}$. In our study, the main risk factors for injury severity were riding in the incorrect lane direction $(O R=1.26)$, running a red light $(O R=1.75)$, riding in a motor vehicle lane $(O R=1.73)$, and increased riding speed $(15-39 \mathrm{~km} / \mathrm{h}, \mathrm{OR}=1.29, \geq 40 \mathrm{~km} / \mathrm{h}, \mathrm{OR}=4.00)$. Conversely, helmet use and riding speed $\leq 15 \mathrm{~km} / \mathrm{h}$ were protective against 
serious injury (ORs $=0.56$ and 0.78 , respectively). The most common injury region was the extremities (99 riders, $48.3 \%)$, followed by the head and face (54 riders, $26.3 \%)$.

All of these traffic violation behaviors might be particular to workers in the delivery industry. These occupational populations do not possess high education levels and high safety consciousness. In order to save time, courier and delivery e-bike riders often choose the nearest shortcut to reach their destination. In order to collect more orders to earn more money, or to contact customers to confirm the delivery address is accessible, workers often use mobile phone when riding. In our study, $34.6 \%$ of interviewees who had a crash were using mobile phone at the time of the crash.

According to the road traffic safety law implemented by the Chinese government, e-bikes are classified as non-motor

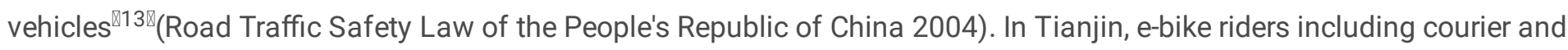
take-out food delivery workers do not need to pass any driver's license test, and therefore may be not aware of the traffic safety rules; this situation is the same in other cities in China ${ }^{\circledR 14}$ (Hu et al.2014). On the other hand, many e-bikes owned by courier and take-out food deliveryman are modified, and may be too heavy or have their speed limiting device removed, both forbidden acts. According to China's criteria, the top speed of e-bikes is about $20 \mathrm{~km} / \mathrm{h}$ and the vehicle weight is less than

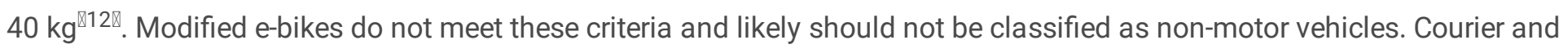
take-out food delivery e-bike riders are in a more vulnerable position than other non-motor vehicle vulnerable road users, because they are often high-mobility migrants who appear to have lower income, lower education level, high-intensity and fast-paced work requirements, and required fast delivery speed. Therefore, this special industry population needs to be given more attention by both government and society, and traffic laws need to be modified and improved to reduce the crash and injury burden in this group.

\section{Study limitations}

The study has several limitations. First, the helmet use rate we observed might be different from that of other seasons due to temperature differences. Second, the speed of observed e-bikes was estimated by well trained and experienced observers, but these observations undoubtedly included error. It would be preferable in future studies to quantify e-bike speeds using measuring instrumentation. Finally, it is possible that some of the e-bike riders' interview responses to the survey were influenced by social desirability bias.

\section{Conclusions}

Our study suggests that courier and take-out food delivery worker e-bike riders are highly vulnerable road users. Road traffic violation behaviors were very common among the riders we observed and interviewed, and this group also had a heavy burden of associated crashes and injuries.. Riding in the incorrect lane direction, running red lights, riding in motor vehicle lanes, speeding, not using a helmet, and using a cell phone while riding all increase the risk of a traffic crash and resulting injury. Three quarters of the riders interviewed reported having had a traffic injury. More than a quarter of these crashes involved a collision with another E-bike, almost a quarter involved pedestrians, and a quarter involved bicycles. Three quarters of the crashes occurred at an intersection or in a non-motor vehicle lane. Road safety concerns need to be communicated to these employees, and establishment or improvement of E- bike regulations are needed to increase safety in this vulnerable occupational group.

\section{Declarations}

\section{Acknowledgments}

This project was supported by funds from the International Federation of Red Cross and Red Crescent Societies as the hosting agency of the Global Road Safety Partnership.

\section{Funding}


This project was supported by funds of Global Road Safety Partnership (RSGP-0233).

\section{Competing interests}

All authors declare that they have no competing interests.

\section{Ethics approval and consent to participate}

The study was approved by the institutional ethics committee of Tianjin Centers for Diseases Control and Prevention. The participants were informed about the purpose of the study before they answered the questionnaire.Moreover,both observation record and investigation were anonymous and didn't involve sensitive information.

\section{Authors' contributions}

Zhuo Wang, Non-communicable diseases control and prevention institute, Tianjin centers for diseases control and prevention,Tianjin,China

Guohong Jiang, Non-communicable diseases control and prevention institute, Tianjin centers for diseases control and prevention,Tianjin,China

Richard L. Neitzel, University of Michigan School of Public Health, Ann Arbor, Michigan, USA

Wenlong Zheng, Non-communicable diseases control and prevention institute, Tianjin centers for diseases control and prevention,Tianjin,China

Wang Dezheng, Non-communicable diseases control and prevention institute, Tianjin centers for diseases control and prevention,Tianjin,China

Xiaodan Xue, Non-communicable diseases control and prevention institute, Tianjin centers for diseases control and prevention,Tianjin,China

Corresponding author

Zhuo Wang

Postal address : Tianjin Centers for Diseases Control and Prevention, Tianjin, China, No.6 Huayue Ave. He Dong Dist.Tianjin, China, 300011

E-mail: wangzhuo521@126.com

Telephone:86- 22-24333559

\section{References}

$1 \rrbracket$ Jiang bo,Zhu qin. Investigation and analysis of talent demand status in China's express delivery industry.

\2₫Zhang XJ, Cui MJ, Gu Y,et al.Trends in Electric Bike- Related Injury in China, 2004-2010.Asia Pac J of Public Health.2015;27(2):1819-26.

$\varangle 3 \llbracket$ Du W, Yang J, Powis Brent, et al. Understanding on-road practices of electric bike riders: An observational study in a developed city of China. Accid Anal Prev.2013;59:319-326.

$\llbracket 4 \llbracket W u$ JD,Peng ZL.Tianjin statistical yearbook 2017.China Statistics Press.2017.64.ISBN 978-7-5037-8265-7. 
\5凶Sylvana Papoutsi, LucaMartinolli, Christian Tasso Braun,et al. E-Bike Injuries: Experience from an Urban Emergency Department-A Retrospective Study from Switzerland. Emergency Medicine International. 2014, Article ID 850236, 5 pages.

\6खYuan Q,Yang HQ,Huang J,et al. What factors impact injury severity of vehicle to electric bike crashes in China? Advances in Mechanical Engineering..2017;8(9):1-10.

\7囚S Haustein, M Møller. E-bike safety: individual-level factors and incident characteristics. J Transp Health.2016;3:386-394.

\8 Schepers JP, Fishman E, Hertog PD, et al. The safety of electrically assisted bicycles compared to classic bicycles.

Accident Anal Prev.2014;73:174-180.

\9खWorld Health Organization Geneva Switzerland. The top 10 causes of death. Available at:

http://www.who.int/mediacentre/factsheets/fs310/en/. Accessed on 4 January 2016.

\10邓Xie SH, Wu YS, Liu XJ, et al. Mortality from road traffic accidents in a rapidly urbanizing Chinese city: A 20-year analysis in Shenzhen,1994-2013.Traffic Inj Prev.2016;17(1):39-43.

$11 \varangle \mathrm{Du}$ W, Yang J, Powis Brent, et al. Understanding on-road practices of electric bike riders: An observational study in a developed city of China. Accid Anal Prev.2013;59:319-326.

Q12ðJie Yang,Yihe Hu, Wei Du,et al.Unsafe riding practice among electric bikers in Suzhou, China:an observational study.

\13囚Zhang XJ, Cui MJ, Gu Y,et al.Trends in Electric Bike- Related Injury in China, 2004-2010.Asia Pac J of Public Health.2015;27(2):1819-26.

\11هDu W, Yang J, Powis Brent, et al. Understanding on-road practices of electric bike riders: An observational study in a developed city of China. Accid Anal Prev.2013;59:319-326.

\12邓Jie Yang,Yihe Hu, Wei Du,et al.Unsafe riding practice among electric bikers in Suzhou, China:an observational study.

$13 \otimes C h i n a$ National People's Congress (2004). Law of the People's Republic of China on road traffic safety. Beijing, 2004.

\14囚Feng Hu , Donglai Lv, Jie Zhu,Jian Fang. Related Risk Factors for Injury Severity of E-bike and Bicycle Crashes in Hefei. Traffic Inj Prev. 2014;15,319-323.

\15囚Feng Hu, Donglai Lv, Jie Zhu,et al.Related Risk Factors for Injury Severity of E-bike and Bicycle Crashes in Hefei. Traffic Injury Prevention (2014) 15, 319-323.

Q16هNantulya VM. Introduction: the global challenge of road traffic injuries: can we achieve equity in safety? Inj Contr Saf Promot. 2003;10:3-7.

\17هDuan LL, Wu CM, Deng X, et al. Road traffic injuries in China,2006-2008. J Public Health Prev Med. 2010;21(3):10-13.

\18هNantulya VM, Reich MR. The neglected epidemic road traffic injuries in developing countries. Br Med J.

2002;324:1139-1141.

ه19 $₫$ Sheng Ang Zhou, MMa, Andrew Fu Wah Ho,et al.Electric bicycle-related injuries presenting to a provincial hospital in China. Medicine .2017, 96:26

\section{Tables}

Table 1 Information items collected by anonymous survey 


\begin{tabular}{|l|l|}
\hline $\begin{array}{l}\text { Basic } \\
\text { information }\end{array}$ & $\begin{array}{l}\text { Gender, age, specific occupation (courier or food delivery), status of registered residence (Tianjin urban, Tianjin } \\
\text { rural, or other provincial), employment duration, and average number of working days per week,previous crashes } \\
\text { and injuries resulting from e-bike riding }\end{array}$ \\
\hline $\begin{array}{l}\text { Specific crash } \\
\text { information } \\
\text { collected by } \\
\text { questions }\end{array}$ & $\begin{array}{l}\text { Whether or not the rider had experienced a crash; the time of the crash(es); specific information about the worst } \\
\text { crash, including riding status, crash site, the other party in the crash, injury severity level, injury location, riding } \\
\text { behaviors, and protective behaviors. The burden of the traffic injuries was also assessed, including medical cost } \\
\text { and lost work time. }\end{array}$ \\
\hline
\end{tabular}

Table 2 Incidence rate of riding behavior among courier and take-out food delivery E-bike riders by observation (\%)

\begin{tabular}{|c|c|c|c|c|c|c|c|c|c|}
\hline \multirow[t]{2}{*}{ Behavior } & & \multicolumn{2}{|c|}{ Daytime $(n=300)$} & \multicolumn{2}{|c|}{ Night(n=300) } & \multicolumn{2}{|c|}{ Total $(n=600)$} & \multirow[t]{2}{*}{ Value } & \multirow{2}{*}{$\begin{array}{c}\mathrm{P} \\
\text { Value }\end{array}$} \\
\hline & & $\mathrm{n}$ & $\%$ & $\mathrm{n}$ & $\%$ & $\mathrm{n}$ & $\%$ & & \\
\hline \multirow{6}{*}{$\begin{array}{l}\text { Traffic } \\
\text { violation }\end{array}$} & Speed over & 271 & 90.3 & 277 & 92.3 & 548 & 91.3 & 0.758 & 0.384 \\
\hline & $\begin{array}{l}\text { Riding in } \\
\text { incorrect lane }\end{array}$ & 50 & 16.7 & 52 & 17.3 & 102 & 17.0 & 0.047 & 0.828 \\
\hline & $\begin{array}{l}\text { direction } \\
\text { Riding in motor } \\
\text { vehicle lane }\end{array}$ & 101 & 33.7 & 96 & 32.0 & 197 & 32.8 & 0.189 & 0.664 \\
\hline & $\begin{array}{l}\text { Run a red light } \\
\text { Don't wait behind } \\
\text { the white line at } \\
\text { red liaht }\end{array}$ & $\begin{array}{l}53 \\
68\end{array}$ & $\begin{array}{l}17.7 \\
22.7\end{array}$ & $\begin{array}{l}58 \\
72\end{array}$ & $\begin{array}{l}19.3 \\
24.0\end{array}$ & $\begin{array}{l}111 \\
140\end{array}$ & $\begin{array}{l}18.5 \\
23.3\end{array}$ & $\begin{array}{l}0.276 \\
0.149\end{array}$ & $\begin{array}{l}0.599 \\
0.699\end{array}$ \\
\hline & Use cell phone & 62 & 20.7 & 65 & 21.7 & 127 & 21.2 & 0.354 & 0.552 \\
\hline & $\begin{array}{l}\text { Use } \\
\text { windshield during } \\
\text { winter }\end{array}$ & 277 & 92.3 & 270 & 90.0 & 547 & 91.2 & 1.014 & 0.314 \\
\hline Protective & Wear helmet * & 219 & 73.0 & 194 & 64.7 & 413 & 68.8 & 4.856 & $0.028 *$ \\
\hline behaviors & $\begin{array}{l}\text { Reflectors using } \\
\text { Turn on light } \\
\text { during night } \\
\text { riding }\end{array}$ & $\begin{array}{l}229 \\
-\end{array}$ & $\begin{array}{l}76.3 \\
-\end{array}$ & $\begin{array}{l}236 \\
248\end{array}$ & $\begin{array}{l}78.7 \\
82.7\end{array}$ & 465 & 77.5 & 0.468 & 0.494 \\
\hline
\end{tabular}

Pearson's chi-square test, ${ }^{*} \mathrm{P}<0.05$

Table 3 Retrospective information of the traffic accident by face-to-face investigation $(\mathrm{N}=367)$ 


\begin{tabular}{|c|c|c|c|c|c|c|c|c|}
\hline & \multicolumn{2}{|c|}{$\begin{array}{l}\text { Right } \\
\text { direction } \\
(\mathrm{n}=238)\end{array}$} & \multicolumn{2}{|c|}{$\begin{array}{l}\text { Wrong direction } \\
(\mathrm{n}=129)\end{array}$} & \multicolumn{2}{|c|}{ Subtotal } & \multirow[t]{2}{*}{ Value } & \multirow[t]{2}{*}{$\begin{array}{l}\mathrm{P}- \\
\text { Value }\end{array}$} \\
\hline & $\mathrm{n}$ & $\%$ & $\mathrm{n}$ & $\%$ & $\mathrm{n}$ & $\%$ & & \\
\hline Crashed into & & & & & & & 7.334 & $0.291^{b}$ \\
\hline Other e-bike & 54 & 22.7 & 40 & 31.0 & 94 & 25.6 & 3.038 & $0.081^{\mathrm{a}}$ \\
\hline Pedestrian & 55 & 23.1 & 35 & 27.1 & 90 & 24.5 & 0.731 & $0.392^{\mathrm{a}}$ \\
\hline Bicycle & 59 & 24.8 & 29 & 22.5 & 88 & 24.0 & 0.245 & $0.621^{\mathrm{a}}$ \\
\hline Motor vehicles & 45 & 18.9 & 16 & 12.4 & 61 & 16.6 & 2.554 & $0.141^{\mathrm{a}}$ \\
\hline Motorbike & 11 & 4.6 & 5 & 3.9 & 16 & 4.4 & 0.112 & $1.000^{\mathrm{a}}$ \\
\hline Other road user & 14 & 4.6 & 4 & 3.1 & 18 & 4.9 & 1.388 & $0.315^{a}$ \\
\hline Accident site & & & & & & & 7.842 & $0.049 * b$ \\
\hline Intersection & 118 & 49.6 & 46 & 35.7 & 164 & 44.7 & 6.559 & $0.010 * a$ \\
\hline Non-motor vehicle lane & 74 & 31.1 & 48 & 37.2 & 122 & 33.2 & 1.410 & $0.235^{\mathrm{a}}$ \\
\hline Motor vehicle lane & 31 & 13.0 & 20 & 15.5 & 51 & 13.9 & 0.430 & $0.512^{\mathrm{a}}$ \\
\hline Sidewalk & 15 & 6.3 & 15 & 11.6 & 30 & 8.2 & 3.161 & $0.109^{\mathrm{a}}$ \\
\hline Injury information & & & & & & & 4.077 & $0.130^{b}$ \\
\hline $\begin{array}{l}\text { Unhurt } \\
\text { Hurt }\end{array}$ & 130 & $\begin{array}{l}54.6 \\
45.4\end{array}$ & 63 & $\begin{array}{l}48.8 \\
51.2\end{array}$ & 193 & $\begin{array}{l}52.6 \\
474\end{array}$ & 1.123 & $0.325^{\mathrm{a}}$ \\
\hline Severity level & & & & & & & & \\
\hline Light & 91 & 38.2 & 57 & 44.2 & 148 & 40.3 & 1.231 & $0.316^{\mathrm{a}}$ \\
\hline Medium & 17 & 7.1 & 7 & 5.4 & 24 & 6.5 & 11.075 & $0.002 * a$ \\
\hline Serious & 0 & 0.0 & 2 & 1.6 & 2 & 0.5 & 47.377 & $0.000 * \mathrm{a}$ \\
\hline
\end{tabular}

a๑Compare with different direction in the group

$\mathrm{b} ₫$ Compare among groups

$* \square \mathrm{P}<0.05$

Table 4 incidence of riding behaviors and OR (95\%CI) between injured and uninjured courier and food delivery e-bike riders who had accident $(n=367)$ 


\begin{tabular}{|c|c|c|c|c|c|c|c|c|c|c|}
\hline & & \multicolumn{2}{|c|}{ Injured $(\mathrm{n}=174)$} & \multicolumn{2}{|c|}{ Unhurt(n=193) } & \multicolumn{2}{|c|}{$\begin{array}{l}\text { Subtotal } \\
(n=367)\end{array}$} & \multirow[t]{2}{*}{ Value } & \multirow[t]{2}{*}{$\begin{array}{l}\mathrm{P} \\
\text { Value }\end{array}$} & \multirow[t]{2}{*}{ OR (95\%CI) } \\
\hline & & $\mathrm{n}$ & $\%$ & $\mathrm{n}$ & $\%$ & $\mathrm{n}$ & $\%$ & & & \\
\hline \multirow{5}{*}{$\begin{array}{l}\text { Traffic } \\
\text { violation } \\
\text { behavior }\end{array}$} & $\begin{array}{l}\text { Riding in } \\
\text { incorrect }\end{array}$ & 66 & 37.9 & 63 & 32.6 & 129 & 35.2 & 1.123 & 0.289 & $\begin{array}{l}1.26 \\
(0.82,1.94)\end{array}$ \\
\hline & $\begin{array}{l}\text { lane } \\
\text { direction }\end{array}$ & & & & & & & & & \\
\hline & $\begin{array}{l}\text { Using } \\
\text { mobile } \\
\text { phone }\end{array}$ & 53 & 30.5 & 74 & 38.3 & 127 & 34.6 & 2.512 & 0.113 & $\begin{array}{l}0.70 \\
(0.46,1.09)\end{array}$ \\
\hline & Running a & 36 & 20.7 & 25 & 13.0 & 61 & 16.6 & 3.952 & 0.047 & \multirow{2}{*}{$\begin{array}{l}1.75 \\
(1.01,3.06) \\
1.73 \\
(0.75,3.95)\end{array}$} \\
\hline & $\begin{array}{l}\text { Riding in } \\
\text { motor } \\
\text { vehicle } \\
\text { lane }\end{array}$ & 15 & 8.6 & 10 & 5.2 & 25 & 6.8 & 1.705 & 0.192 & \\
\hline \multirow{4}{*}{$\begin{array}{l}\text { Riding } \\
\text { speed }\end{array}$} & $\leq 15 \mathrm{~km} / \mathrm{h}$ & 43 & 24.7 & 57 & 29.5 & 100 & 27.3 & 1.073 & 0.300 & \multirow{4}{*}{$\begin{array}{l}0.78 \\
(0.49,1.24) \\
1.29 \\
(0.85,1.96) \\
4.00 \\
(0.82,19.53) \\
0.63 \\
(0.32,1.25)\end{array}$} \\
\hline & $\begin{array}{l}15-39 \\
\mathrm{~km} / \mathrm{h}\end{array}$ & 109 & 62.6 & 109 & 56.5 & 218 & 59.4 & 1.443 & 0.230 & \\
\hline & $\geq 40 \mathrm{~km} / \mathrm{h}$ & 7 & 4.0 & 2 & 1.04 & 9 & 2.5 & 3.412 & 0.065 & \\
\hline & Unclear & 15 & 8.6 & 25 & 13.0 & 40 & 10.9 & 1.769 & 0.184 & \\
\hline \multirow{3}{*}{$\begin{array}{l}\text { Protective } \\
\text { behaviors }\end{array}$} & Wear & 90 & 51.7 & 127 & 65.8 & 217 & 59.1 & 7.505 & 0.006 & \multirow{3}{*}{$\begin{array}{l}0.56 \\
(0.37,0.86) \\
1.35 \\
(0.89,2.03) \\
0.99 \\
(0.62,1.59)\end{array}$} \\
\hline & $\begin{array}{l}\text { Reflectors } \\
\text { using }\end{array}$ & 94 & 54.0 & 90 & 46.6 & 184 & 50.1 & 1.999 & 0.157 & \\
\hline & $\begin{array}{l}\text { None of } \\
\text { above }\end{array}$ & 43 & 24.7 & 48 & 24.9 & 91 & 24.8 & 0.001 & 0.972 & \\
\hline
\end{tabular}

Pearson's chi-square test

\section{Figures}

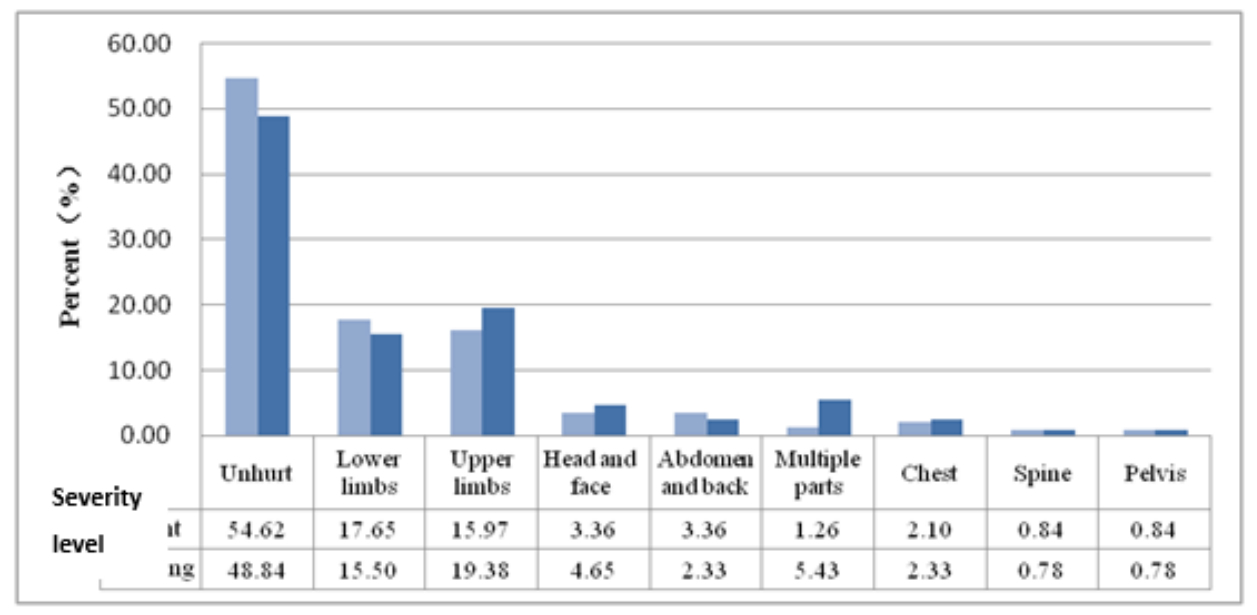

Figure 1

Injury information among e-bike riders riding in right $(\mathrm{n}=238)$ and wrong $(\mathrm{n}=129)$ direction

\section{Supplementary Files}

This is a list of supplementary files associated with this preprint. Click to download. 
- supplementary.doc

Page 13/13 